\title{
Chemical and physical evaluation, antioxidant and digestibility profiles of white and pigmented rice from different areas of Indonesia
}

\author{
Avaliação química e física, perfis de antioxidantes $e$ \\ digestibilidade de arroz branco e pigmentado de diferentes \\ áreas da Indonésia
}

\author{
Nancy Dewi Yuliana ${ }^{1^{*}}$ (D), Muhamad Arif Akhbar ${ }^{1}$ \\ ${ }^{1}$ Bogor Agricultural University, Faculty of Agroindustrial Technology and Engineering, Department of Food Science \\ and Technology, IPB Dramaga Campus, Jalan Raya Dramaga - Indonesia \\ ${ }^{*}$ Corresponding Author: Nancy Dewi Yuliana, Bogor Agricultural University, Faculty of Agroindustrial Technology \\ and Engineering, Department of Food Science and Technology, IPB Dramaga Campus, PO BOX 220, Bogor \\ 16002, Jalan Raya Dramaga - Indonesia, e-mail: nancy_dewi@ipb.ac.id
}

Cite as: Yuliana, N. D., \& Akhbar, M. A. (2020). Chemical and physical evaluation, antioxidant and digestibility profiles of white and pigmented rice from different areas of Indonesia. Brazilian Journal of Food Technology, 23, e2018238. https://doi.org/10.1590/1981-6723.23818

\begin{abstract}
Black rice and red rice are often claimed to have more health benefits than white rice. They have been reported to have greater antioxidant activity and lower digestibility than white rice, functional properties which are important to prevent the metabolic disorders related to diseases such as diabetes. However, rice grown in different areas or subjected to different processing has shown different physical, chemical and functional properties. Thus the objectives of this study were to determine the physical properties (hardness, colour and gelatinization profile), chemical properties (proximate composition, total phenolic and flavonoid contents, antioxidant capacity), and the in vitro digestibility of Solok black rice (SBR), Solok red rice (SRR), Tangerang black rice (TBR), Cianjur red rice (CRR) and Cianjur white rice (CWR) cultivated in different areas in Indonesia. The results revealed that rice cultivated in different areas showed different physical characteristics and chemical compositions. The In vitro analysis of the digestibility of the starch with $\alpha$-amylase showed that pigmented rice was less digestible (56.10\% to $83.43 \%$ ) than white rice (87.35\%). A normal cooking method commonly used in society was found to significantly reduce the total phenolic content, flavonoids and antioxidant capacity of the rice.
\end{abstract}

Keywords: Starch; Phenolic content; Flavonoids.

\section{Resumo}

Frequentemente, alegam que arroz negro e arroz vermelho têm mais benefícios para a saúde que arroz branco. Tem sido relatado que eles têm maior atividade antioxidante e menor digestibilidade que arroz branco, propriedades funcionais que são importantes na prevenção de desordens metabólicas relacionadas com doenças, 
como diabete. Contudo, arroz cultivado em áreas diferentes ou submetido a processos diferentes tem apresentado propriedades físicas, químicas e funcionais diferentes. Portanto, o objetivo deste estudo foi determinar as propriedades físicas (dureza, cor e perfil de gelatinização) e químicas (composição centesimal, conteúdos totais de compostos fenólicos e flavonoides, e capacidade antioxidante) e a digestibilidade in vitro de arroz negro Solok (SBR), arroz vermelho Solok (SRR), arroz negro Tangerang (TBR), arroz vermelho Cianjur (CRR) e arroz branco Cianjur (CWR), cultivados em áreas diferentes da Indonésia. Os resultados demonstraram que as amostras de arroz cultivado em áreas diferentes apresentaram características físicas e composições químicas diferentes. A análise in vitro da digestibilidade do amido com $\alpha$-amilase mostrou que o arroz pigmentado foi menos digestível (56,10\% a 83,43\%) que arroz branco (87,35\%). Mostrou-se que o método de cozimento normal comumente usado pela sociedade reduziu, significativamente, os conteúdos totais de compostos fenólicos e flavonoides, e a capacidade antioxidante do arroz.

Palavras-chave: Amido; Conteúdo fenólico; Flavonoides.

\section{Introduction}

Rice is an important staple food in many countries including Indonesia. White rice is the main type of rice consumed by Indonesian people, but Indonesia has other types of rice, including black rice and brown rice. Cianjur, Solok and Tangerang are the three major rice producing districts in the country. Cianjur and Tangerang are located on Java Island whereas Solok is on Sumatera Island. The geographical and climatic conditions of the three regions are quite different as shown in Table 1. Pigmented rice is often claimed to be healthier than white rice. Brown rice and black rice have been reported as potential sources of antioxidants (Yawadio et al., 2007) due to their higher levels of phenolic compounds and anthocyanins: as compared to unpigmented rice.

Table 1. Geographical and climatic conditions of the Cianjur ${ }^{1}$, Solok $^{2}$ and Tangerang ${ }^{3}$ regions.

\begin{tabular}{ccccc}
\hline No & Region & $\begin{array}{c}\text { Average } \\
\text { Temperature }\left({ }^{\circ} \mathbf{C}\right)\end{array}$ & Rainfall (mm/year) & $\begin{array}{c}\text { Height above sea } \\
\text { level (m) }\end{array}$ \\
\hline 1 & Cianjur & $18-24$ & 228 & 450 \\
\hline 2 & Solok & $26.1-28.9$ & 184.31 & 390 \\
\hline 3 & Tangerang & $21.5-34.1$ & 10.9 & 85 \\
\hline
\end{tabular}

${ }^{1}$ Official Website of Cianjur District (2013); ${ }^{2}$ Badan Pusat Statistik (2013); ${ }^{3}$ Badan Pusat Statistik (2012).

The distribution of the phenolic acids in the different parts of pigmented and unpigmented rice was reported by Shao et al. (2014). The highest phenolic acid content in non-pigmented rice was found in the embryo, while in pigmented rice, it was found in the bran. In the same study, pigmented rice showed a higher total phenolic compounds content than unpigmented rice. These phenolic compounds were associated with the antioxidant capacity of the rice as measured by the DPPH and ORAC methods. In a more recent study, fifteen rice genotypes consisting of 5 unpigmented rice varieties, 5 red rice varieties and 5 black rice varieties were shown to have a quite wide variation in their contents of phenolic compounds, flavonoids, pro-anthocyanidins, anthocyanins and minerals. As expected, the phenolic compounds, flavonoids and anthocyanins showed a strong correlation with the antioxidant capacity of the rice (Shao et al., 2018).

The phytochemicals found in the rice were also reported to possess cytotoxic activity. Peonidin 3-glucoside and cyanidin 3-glucoside, which are the major anthocyanins in black rice, showed significant inhibitory activity against the growth of several human cancer cell lines (human hepatocellular carcinoma SKHep-1 and Huh-7, human cervical carcinoma HeLa, and a human tongue squamous cell carcinoma SCC-4) (Chen et al., 2006). 
The abovementioned studies revealed that it is important to carry out research on the physicochemical and functional properties of different rice varieties grown in different areas, including those of the Indonesian rice varieties. Many factors might influence the phytochemical composition of the rice and thus their bioactivity might also be different. Up to the present moment, the study of Indonesian rice with respect to this topic, has been limited. In this study the physical and chemical properties and in vitro digestibility of black, red and white rice from Cianjur, Solok and Tangerang were studied. In addition, the effects of cooking on the abovementioned parameters were determined. The results of this research are important to give scientific explanations for the health benefits claimed for these pigmented rice varieties.

\section{Material and methods}

\subsection{Materials}

The red and black rice were obtained from two different regions while the white rice only came from one region. Cianjur white rice was bought from the traditional market in Bogor (West Java Province, Indonesia). Black rice was purchased from farmers in Solok (West Sumatra Province, Indonesia) and in Tangerang (Tangerang province, Indonesia). Red rice was bought from farmers in Solok (West Sumatra Province, Indonesia) and in Cianjur (West Java Province, Indonesia). The chemicals used in this experiment were acquired from Sigma Aldrich (Germany) and were of analytical grade, as follows: $n$-hexane, potassium sulphate $\left(\mathrm{K}_{2} \mathrm{SO}_{4}\right)$, mercuric oxide $(\mathrm{HgO}), 95 \%$ sulphuric acid $\left(\mathrm{H}_{2} \mathrm{SO}_{4}\right)$, distilled water, boric acid $\left(\mathrm{H}_{3} \mathrm{BO}_{3}\right)$, methylene red and methylene blue indicators, sodium hydroxide $(\mathrm{NaOH})$, sodium thiosulfate $\left(\mathrm{Na}_{2} \mathrm{~S}_{2} \mathrm{O}_{3}\right)$, $0.02 \mathrm{~N}$ hydrochloric acid $(\mathrm{HCl})$, gallic acid standard, ethanol, Folin-Ciocalteau reagent, sodium carbonate $\left(\mathrm{Na}_{2} \mathrm{CO}_{3}\right)$, ascorbic acid, methanol, $0.1 \mathrm{M}$ acetate buffer $\mathrm{pH}$ 5.0, 2,2-diphenyl-1-picrylhydrazyl (DPPH), standard quercetin ( $\geq 95 \%)$, sodium nitrite $\left(\mathrm{NaNO}_{2}\right)$, aluminium chloride $\left(\mathrm{AlCl}_{3}\right), 3,5$ dinitrosalicylic acid (DNS), starch standard, $20 \mathrm{mM}$ phosphate buffer $(\mathrm{pH} 6.9), 6.7 \mathrm{mM}$ sodium chloride $(\mathrm{NaCl})$, potassium sodium tartrate $\left(\mathrm{KNaC}_{4} \mathrm{H}_{4} \mathrm{O}_{6}\right)$, maltose, $\alpha$-amylase enzyme, and dimethyl sulfoxide (DMSO).

\subsection{Colour measurement}

The colour was measured using the Hunter L, a, b colour scale chromameter according to the procedure described in the manual (Hunter, VA, USA). The data were denoted by L, a and $b$ where $\mathrm{L}$ represents the level of brightness with a value from 0 to 100 and $\mathrm{a}$ and $\mathrm{b}$ represent the chromatic colour between red to green and yellow to blue, respectively, with values ranging from -80 to +80 and from -70 to +70 , respectively. The analyses were carried out in triplicate.

\subsection{Gelatinization profile and rice hardness}

The gelatinization profile was determined using the Rapid Visco Analyzer (RVA), (Newport Scientific Pty Ltd., Warriewood, NSW, Australia) according to the manufacturer's instructions. The analysis was carried out as follows: the ground rice sample ( $3 \mathrm{~g}$, moisture content $12 \%$ ) was mixed with $25 \mathrm{~g}$ of distilled water, stirring constantly $(160 \mathrm{rpm})$. The sample was then heated to a temperature of $50{ }^{\circ} \mathrm{C}$ and held there for 1 minute before gradually increasing the temperature from $50^{\circ} \mathrm{C}$ to $95{ }^{\circ} \mathrm{C}$ at $6{ }^{\circ} \mathrm{C} / \mathrm{min}$. The temperature was held at $95{ }^{\circ} \mathrm{C}$ for $5 \mathrm{~min}$ and then decreased to $50{ }^{\circ} \mathrm{C}$ at $6{ }^{\circ} \mathrm{C} / \mathrm{min}$ and held at $50{ }^{\circ} \mathrm{C}$ for $5 \mathrm{~min}$. The peak viscosity, holding viscosity, final viscosity and pasting temperatures were then determined. The rice hardness test was carried out using the Texture Profile Analyzer (TA-XT2, Stable Micro System, Haslemere, Surrey, UK) according to the manufacturer's instructions Using a spherical ball probe $(d=4 \mathrm{~mm})$ with pre-test, test and post-test speeds of $2.0 \mathrm{~mm} / \mathrm{s}, 0.5 \mathrm{~mm} / \mathrm{s}$ and $10 \mathrm{~mm} / \mathrm{s}$, respectively. The distance measured was $15 \mathrm{~mm}$ and the trigger force $205 \mathrm{~g}$. The data acquisition rate was $200 \mathrm{pps}$ (points per second) with a relaxation time 
of $5 \mathrm{~s}$. The hardness level was determined from the peak force value during the first compression cycle and expressed in $\mathrm{N}$ (Newton) units.

\subsection{Determination of the water content}

The water content was determined by a gravimetric method of AOAC 925.10 (Association of Official Analytical Chemists, 2000). The empty aluminium capsule was dried in an oven at $105^{\circ} \mathrm{C}$ for $15 \mathrm{~min}$, cooled in a desiccator for 5 minutes, weighed, and the sample $( \pm 3 \mathrm{~g})$ then added. The capsule containing the sample was returned to the oven and dried at $105^{\circ} \mathrm{C}$ to constant weight.

\subsection{Determination of the total ash content}

The porcelain dish was heated in an oven at $105^{\circ} \mathrm{C}$ for 15 minutes, cooled in a desiccator, and weighed. The sample ( $3 \mathrm{~g})$ was added to the dried dish, placed in a furnace and incinerated to obtain a white ash with constant weight (Association of Official Analytical Chemists, 2000).

\subsection{Determination of the protein content}

The protein content was determined using the Micro Kjeldahl Method of AOAC 991.20 (Association of Official Analytical Chemists, 2000), which consists of three main steps: sample digestion ( $\pm 0.2 \mathrm{~g})$ using $2 \mathrm{~mL}$ of concentrated $\mathrm{H}_{2} \mathrm{SO}_{4}$ plus the catalyst ( $2 \mathrm{~g}$ of $\mathrm{K}_{2} \mathrm{SO}_{4}$ plus $50 \mathrm{mg} \mathrm{HgO}$ ) in a water bath, followed by distillation of the denatured sample with $5 \mathrm{~mL} 0.5 \mathrm{~N} \mathrm{H}_{3} \mathrm{BO}_{3}, 2$ drops of methylene red/methylene blue indicator and $10 \mathrm{~mL}$ of the $\mathrm{NaOH}-\mathrm{Na}_{2} \mathrm{~S}_{2} \mathrm{O}_{3}$ reagent until $\pm 50 \mathrm{~mL}$ distillate was obtained, and finally titration of the distillate with $0.02 \mathrm{~N} \mathrm{HCl}$ to a colour change from green to grey. The same procedure was carried out for the blanks.

\subsection{Determination of the total fat content}

The total fat content was determined using the Soxhlet Method of AOAC 922.06 (Association of Official Analytical Chemists, 2000). Fat free soxhlet flasks were dried in an oven, cooled in a desiccator and weighed. The samples $( \pm 3 \mathrm{~g})$ wrapped in filter paper, were refluxed for \pm 5 hours and the flask then dried in an oven at $105^{\circ} \mathrm{C}$ to constant weight.

\subsection{Determination of the carbohydrate content}

The carbohydrate content was calculated by difference according to AOAC 986.25 method (Association of Official Analytical Chemists, 2000).

\subsection{Determination of the starch digestibility}

The starch digestibility was determined using raw and cooked rice. The rice was cooked using a protocol commonly used in Indonesia. First it was soaked in water $(90 \mathrm{~min})$ and then cooked by boiling in water with a $1: 1 \mathrm{w} / \mathrm{w}$ ratio for approximately $30 \mathrm{~min}$ until all the water evaporated. For the pigmented rice, a 3-times greater volume of water was used. A standard curve was prepared using $1 \mathrm{~mL}$ aliquots of standard maltose solutions with concentrations of $0.0,0.1,0.2,0.3,0.4$ and $0.5 \mathrm{mg} / \mathrm{mL}$ and $2 \mathrm{~mL}$ of DNS reagent (made from $10 \mathrm{~g}$ 3,4-dinitrosalicyclic acid, $403 \mathrm{~g} \mathrm{KNaC}_{4} \mathrm{H}_{4} \mathrm{O}_{6}$ and $16 \mathrm{~g} \mathrm{NaOH}$, dissolved in $1 \mathrm{~L}$ distilled water) in test tubes. The tubes were heated in a boiling water bath for $12 \mathrm{~min}$, immediately cooled with running water, $10 \mathrm{~mL}$ of distilled water added to the solution, the mixture vortexed until homogeneous and the absorbance measured by UV-Vis spectrophotometer at a wavelength of $520 \mathrm{~nm}$. For the analyses of the samples, $100 \mathrm{mg}$ of powdered rice were put into a test tube, $10 \mathrm{~mL}$ of distilled water added, the tube covered with aluminium 
foil, vortexed for 30 seconds, heated in a water bath at a temperature of $90{ }^{\circ} \mathrm{C}$ for $30 \mathrm{~min}$, and then cooled. The cooled samples were then dissolved in $100 \mathrm{~mL}$ of water in a flask and $1 \mathrm{~mL}$ of sample solution taken, placed in a test tube, and $1.5 \mathrm{~mL}$ of distilled water and $2.5 \mathrm{~mL}$ of $0.1 \mathrm{M}$ sodium phosphate buffer $(\mathrm{pH} 7.0)$ added. Two tubes were so prepared, one being used as the blank. The tube was closed and incubated at $37^{\circ} \mathrm{C}$, for $15 \mathrm{~min} .2 .5 \mathrm{~mL}$ of an $\alpha$-amylase enzyme solution were then added $(1 \mathrm{mg} / \mathrm{mL}$ in phosphate buffer solution $\mathrm{pH}$ 7.0) and incubated at $37^{\circ} \mathrm{C}$ for $30 \mathrm{~min} .2 \mathrm{~mL}$ of DNS solution were then added, the solution heated in boiling water for $12 \mathrm{~min}$ and immediately cooled with running water. A total of $10 \mathrm{~mL}$ of distilled water were then added to the solution and stirred until homogeneous using a vortex. The absorbance of the sample and the blank were measured using a UV-Vis spectrophotometer at a wavelength of $520 \mathrm{~nm}$ (Shimadzu, UV-vis, model UV-1800; Tokyo, Japan). The starch digestibility of the sample was calculated as a percentage relative to the starch standard (Anderson et al., 2002).

\subsection{Determination of the total phenolic compound content}

The total phenolic compound content (TPC) was determined using the Folin-Ciocalteau method (Strycharz \& Shetty, 2002). A gallic acid stock solution was first prepared with a concentration of $250 \mathrm{mg} / \mathrm{L}$, for dilution to $50-250 \mathrm{mg} / \mathrm{L} .5 \mathrm{~mL}$ of $95 \%$ ethanol were added to tubes containing $100 \mathrm{mg}$ of each sample and centrifuged at $3000 \mathrm{rpm}$ for $10 \mathrm{~min} .0 .5 \mathrm{~mL}$ of each supernatant and $0.5 \mathrm{~mL}$ of each concentration of standard were placed into clean test tubes, and $0.5 \mathrm{~mL}$ of $95 \%$ ethanol, $2.5 \mathrm{~mL}$ of distilled water and $2.5 \mathrm{~mL}$ of the $50 \%$ Folin-Ciocalteau reagent added to each. The mixtures were allowed to stand for 5 minutes and then $0.5 \mathrm{~mL}$ of $5 \% \mathrm{Na}_{2} \mathrm{CO}_{3}$ were added to each and placed in the dark for $1 \mathrm{~h}$. The absorbance was measured at a wavelength of $725 \mathrm{~nm}$ using a spectrophotometer. The TPC value was estimated using the standard gallic acid curve and the results expressed as $\mathrm{mg}$ of gallic acid equivalent per $\mathrm{g}$ of rice sample.

\subsection{Determination of the antioxidant capacity}

The total antioxidant capacity was measured using the DPPH colorimetric method (Kubo et al., 2002). A standard curve of ascorbic acid (in methanol) was prepared at concentrations of 0, 50, 100, 200, 400 and $500 \mathrm{mg} / \mathrm{L}$. The samples were dissolved in methanol at a ratio of 1: 4, sonicated for $20 \mathrm{~min}$ and centrifuged at $2500 \mathrm{rpm}$ for $10 \mathrm{~min}$. In another test tube, $2 \mathrm{~mL}$ of acetate buffer, $3.75 \mathrm{~mL}$ of methanol and $200 \mu 1$ of DPPH were added and the mixture vortexed. $50 \mu 1$ of each sample solution or standard antioxidant solution (ascorbic acid) and methanol as the negative control were added and vortexed. The mixtures were incubated in the dark at $25^{\circ} \mathrm{C}$ for $\pm 20 \mathrm{~min}$ and the absorbance measured at a wavelength of $517 \mathrm{~nm}$. The antioxidant activity was expressed in AEAC (Ascorbic Acid Equivalent Antioxidant Capacity).

\subsection{Determination of the total flavonoid content}

The total flavonoid content was determined according to a method described elsewhere (Chang et al., 2002). A calibration curve of quercetin was first prepared with concentrations of $0,50,100,200,400,600$, $700,800,900$ and $1000 \mathrm{mg} / \mathrm{L}$ in methanol. $100 \mathrm{~g}$ of each powdered sample were extracted by sonication for $15 \mathrm{~min}$. with $2.5 \mathrm{~mL}$ of methanol, and centrifuged for $10 \mathrm{~min}$ at $3000 \mathrm{rpm} .0 .5 \mathrm{~mL}$ of each sample was mixed with $2 \mathrm{~mL}$ of distilled water and $0.15 \mathrm{~mL}$ of $5 \% \mathrm{NaNO}_{2}$ and allowed to stand for $6 \mathrm{~min} .0 .15 \mathrm{~mL}$ of $10 \%$ $\mathrm{AlCl}_{3}$ was added to the solution and allowed to stand for a further 6 minutes. The solution was then allowed to react with $2 \mathrm{~mL}$ of $4 \% \mathrm{NaOH}$, diluted to a total volume of $5 \mathrm{~mL}$, allowed to stand for 15 minutes and the absorbance measured at a wavelength of $510 \mathrm{~nm}$ using a spectrophotometer. Measurements were also made for the blanks in the form of distilled water. The total flavonoid content was expressed as the mg quercetin equivalents per $\mathrm{g}$ of sample. 


\subsection{Data analysis}

A completely randomized statistical design was used in this study and the analysis carried out in triplicate. The data were analysed using a one-way analysis of variance (ANOVA) and presented as the mean \pm standard deviation. The statistical analysis was carried out using SPSS 17.0 (SPSS Inc., Chicago, IL) and any significant difference between the means compared by Duncan's multiple-range test $(p=0.05)$.

\section{Results and discussion}

Different varieties of rice growing in different places are likely to have different and unique characteristics of flavour, colour, nutrition, chemical composition and cooking properties (Yadav et al., 2007). In another study, black and red rice varieties from different countries (China, Italy, Japan, India, Laos, Thailand, France and Cambodia) were found to have different levels of total flavonoids and total phenolic compound contents. The rice from China was shown to have the highest total phenolic compound and total flavonoids contents, and the highest antioxidant capacity (as measured by the ABTS and DPPH methods) as compared to the rice from the other countries (Sumczynski et al., 2016).

The present study showed findings similar to those described in previous reports, the rice studied showing variations in colour, chemical composition, pasting properties, digestibility and antioxidant capacity, as discussed below.

\subsection{Colour measurement}

Figure 1 shows the visual appearance of the five different rice varieties used in this study. Visually, Solok red rice (Figure 1B) and Cianjur red rice (Figure 1C) are similar. In contrast, Solok black rice (Figure 1D) and Tangerang black rice (Figure 1E) are different. Table 2 shows the results obtained in the colour analysis carried out using the Hunter L, a, b colour scale chromameter.

A.

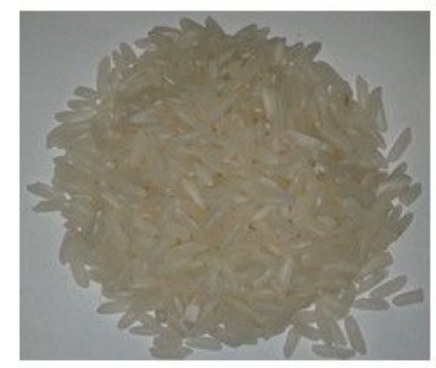

B.

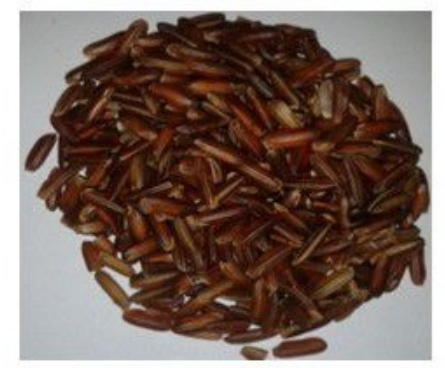

C.

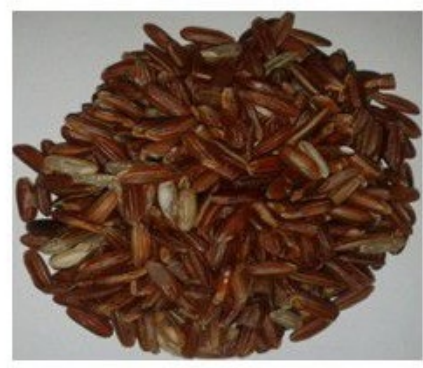

D.

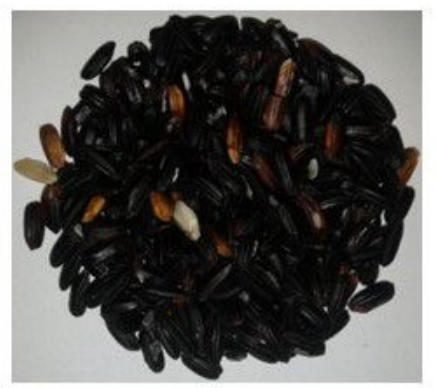

E.

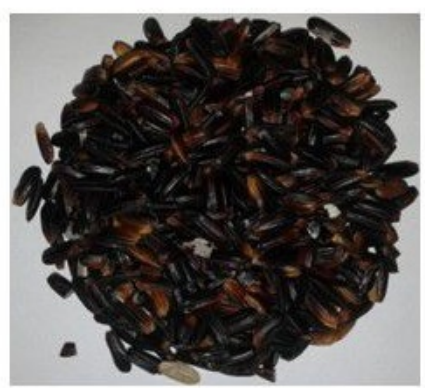

Figure 1. Visual appearance of the five different rice varieties used in this study. (A) Cianjur white rice; (B) Solok red rice; (C) Cianjur red rice; (D) Solok black rice; (E) Tangerang black rice. 
Table 2. Colour profile of the five different rice varieties as expressed in L, a and $b$.

\begin{tabular}{cccc}
\hline Rice & $\mathbf{L}$ & $\mathbf{a}$ & $\mathbf{b}$ \\
\hline SRR & $32.25 \pm 0.29^{\mathrm{c}}$ & $11.60 \pm 0.17^{\mathrm{d}}$ & $12.97 \pm 0.06^{\mathrm{c}}$ \\
\hline CRR & $35.75 \pm 0.04^{\mathrm{d}}$ & $9.87 \pm 0.59^{\mathrm{c}}$ & $13.72 \pm 0.10^{\mathrm{d}}$ \\
\hline SBR & $22.57 \pm 0.32^{\mathrm{a}}$ & $0.47 \pm 0.43^{\mathrm{a}}$ & $0.22 \pm 0.26^{\mathrm{a}}$ \\
\hline TBR & $25.21 \pm 0.04^{\mathrm{b}}$ & $3.50 \pm 0.35^{\mathrm{b}}$ & $2.45 \pm 0.13^{\mathrm{b}}$ \\
\hline CWR & $67.00 .84^{\mathrm{e}}$ & $0.95 \pm 0.19^{\mathrm{a}}$ & $14.04 \pm 0.32^{\mathrm{e}}$ \\
\hline
\end{tabular}

The values are expressed as the mean \pm S.D. $(n=3)$. Means with different letters indicate a significant difference for each parameter measured at $p<0.05$ (Duncan test). $\mathrm{SRR}=$ Solok red rice; $\mathrm{CRR}=$ Cianjur red rice; $\mathrm{SBR}=$ Solok black rice; $\mathrm{TBR}=$ Tangerang black rice; $\mathrm{CWR}=\mathrm{Cianjur}$ white rice.

According to the results presented in Table 2, SBR and CWR did not differ in their yellow colouration, whereas the $b$ values for SRR, CRR and TBR did differ from each other, varying from 2.45 to 13.72 . The sample CRR had higher $\mathrm{L}$ and $\mathrm{b}$ values, which means it was brighter and more yellowish than SRR. However, it had a lower value for a, which means the intensity of its red colour was lower than that of SRR. The colour profile of SBR was quite different from that of TBR, the values obtained for $L$, $a$ and $b$ value showing that SBR was brighter than TBR. In addition to environmental factors, the colour differences found between the rice samples tested were also influenced by genetic factors. As expected, the colour profiles of the pigmented rice varieties were very different from that of the white rice. However, in relation to the red colour, SBR and CWR did not differ significantly one from the other, whereas SRR, CRR and TBR differed with respect to the values of $\mathrm{L}, \mathrm{a}$ and $\mathrm{b}$. Although the anthocyanin contents were not measured in this study, previous reports stated that different types of anthocyanins and pro-anthocyanidins were the phytochemicals responsible for the diverse colours of pigmented rice, and that these were widely distributed in different concentrations in the coloured rice cultivars (Hosoda et al., 2018).

\subsection{Proximate analysis}

The results of the proximate analysis can be seen in Table 3. The samples CRR, SBR, TBR and CWR were not significantly different at $p=0.05$, the only sample that differed from the others being SRR. The water content is one of the important parameters that influences rice quality during storage, and the Indonesian National Standardization Agency or BSN requires that the maximum water content of milled rice be $14 \%$, this being important for long term storage and to avoid insect infestation (Badan Standarisasi Nasional, 2008).

Table 3. Proximate composition of the five different rice varieties from different areas in Indonesia*.

\begin{tabular}{cccccc}
\hline Rice & $\begin{array}{c}\text { Water content } \\
\mathbf{( \% )}\end{array}$ & $\begin{array}{c}\text { Ash content } \\
(\mathbf{\%})\end{array}$ & $\begin{array}{c}\text { Fat content } \\
\mathbf{( \% )}\end{array}$ & $\begin{array}{c}\text { Protein content } \\
\mathbf{( \% )}\end{array}$ & $\begin{array}{c}\text { Carbohydrate content } \\
\mathbf{( \% )}\end{array}$ \\
\hline SRR & $11.47^{\mathrm{a}}$ & $1.28^{\mathrm{c}}$ & $2.46^{\mathrm{d}}$ & $7.21^{\mathrm{b}}$ & $77.59^{\mathrm{cd}}$ \\
\hline CRR & $13.30^{\mathrm{b}}$ & $1.07^{\mathrm{b}}$ & $2.44^{\mathrm{d}}$ & $9.50^{\mathrm{e}}$ & $73.88^{\mathrm{b}}$ \\
\hline SBR & $13.55^{\mathrm{b}}$ & $1.28^{\mathrm{c}}$ & $1.46^{\mathrm{b}}$ & $5.87^{\mathrm{a}}$ & $77.84^{\mathrm{d}}$ \\
\hline TBR & $13.84^{\mathrm{b}}$ & $1.36^{\mathrm{d}}$ & $1.91^{\mathrm{c}}$ & $7.79^{\mathrm{c}}$ & $75.10^{\mathrm{a}}$ \\
\hline CWR & $13.99^{\mathrm{b}}$ & $0.35^{\mathrm{a}}$ & $0.45^{\mathrm{a}}$ & $8.18^{\mathrm{d}}$ & $77.03^{\mathrm{c}}$ \\
\hline
\end{tabular}

*The values are expressed as the mean \pm S.D. $(n=3)$. Means with different letters indicate a significant difference within the parameter measured, at $p<0.05$ (Duncan test). $\mathrm{SRR}=$ Solok red rice; $\mathrm{CRR}=$ Cianjur red rice; $\mathrm{SBR}=$ Solok black rice; $\mathrm{TBR}=\mathrm{Tangerang}$ black rice; $\mathrm{CWR}=$ Cianjur white rice.

The water contents of the rice samples tested in this study were all within the accepted range (11.47-13.99\%). The highest water content was found in CWR, while the lowest was in SRR, results in agreement with previous research elsewhere. The water contents of some red rice varieties from Thailand, Sri Lanka and China were reported by Sompong et al. (2011) to be $12.01 \%, 12.94 \%$ and $11.90 \%$, respectively. In the same study, the water contents of some black rice varieties from Thailand and China were reported as being $12.59 \%$ and $11.26 \%$, respectively. 
The ash contents of the rice varieties studied in the present study ranged from $0.35 \%-1.36 \%$. (Table 3 ). The ash content reflects the total mineral content and there was no significant difference between SRR and SBR for this parameter $(p=0.05)$. However, CRR, TBR and CWR differed from each other with respect to the ash content, ranging from $0.35 \%$ to $1.36 \%$. The mineral content of pigmented rice has been reported to be higher than that of unpigmented rice (Yodmanee et al., 2011), and the ash content of the rice samples studied here was not very different from those studied previously by Sompong et al. (2011), who analysed several red rice varieties from China, Sri Lanka and Thailand and reported ash contents varying between $0.82 \%-1.45 \%$, while some black rice varieties from China and Thailand showed ash contents between $1.42 \%$ $1.74 \%$ (Sompong et al., 2011). In rice the minerals accumulate mainly in the bran and the level of available minerals in the grain was reported to be significantly influenced by the rice genotype and intensity of polishing (Hansen et al., 2012).

The fat contents of the five rice samples tested in this study varied between $0.45 \%-2.46 \%$, which was comparable to those found in a previous report on pigmented rice from Thailand, Sri Lanka and China (Sompong et al., 2011). The SRR and CRR samples did not differ significantly one from the other $(p=0.05)$ but the SBR, TBR and CWR samples varied from $0.45 \%$ to $1.91 \%$. The fat content is associated with the taste of the rice after cooking, rice with a higher fat content being tastier and containing less starch. The fat content of rice is influenced by the intensity of polishing, since the fat mainly accumulates in the bran (Verma \& Srivastav, 2017).

The protein contents of the five rice samples had significant differences at $p=0.05$. The highest protein content was found in the CRR sample (9.50\%), followed by CWR (8.18\%), TBR (7.79\%) and SRR (7.21\%). The lowest protein content was presented by the SBR sample (5.87\%). These results were fairly similar to protein contents of red rice varieties from North America, which varied from 9.9\% to $14.0 \%$ (Gelay \& Bryant, 2009), while Sompong et al. (2011) reported that a number of red and black rice varieties from the regions of Thailand, Sri Lanka and China had protein contents between $7.16 \%$ and $10.36 \%$, also fairly similar to the results of this study. The carbohydrate contents of the five rice samples studied ranged from $73.88 \%$ to $77.84 \%$, with a significant difference found between CRR and TBR $(p=0.05)$, whereas the samples SRR, SBR and CWR showed no significant differences.

\subsection{Rice hardness profile}

The hardness value indicates the resistance to the compressive force applied, and Table 4 shows the results obtained for this characteristic. The SRR sample showed the greatest value for hardness $(8.40 \mathrm{~kg})$ and the SBR sample the smallest. However, there were significant differences between the SRR, SBR and CWR samples, but no significant difference between the CRR and CWR samples $(p>0.05$.)

The hardness of rice has been reported to be associated with the water content, storage conditions and storage time. The SRR sample had the lowest water content (11.47\%), and presented the greatest level for hardness $\left(8.40 \mathrm{~kg}\right.$ ). Rice stored at higher temperatures (for example, $40{ }^{\circ} \mathrm{C}$ ) was harder than rice stored at temperatures below $40{ }^{\circ} \mathrm{C}$ (Park et al., 2012).

Table 4. Hardness levels of the five different rice varieties from different areas in Indonesia*.

\begin{tabular}{cc}
\hline Rice & Hardness (kgf) \\
\hline SRR & $8.40 \pm 0.00^{\mathrm{d}}$ \\
\hline SBR & $6.65 \pm 0.15^{\mathrm{a}}$ \\
\hline CRR & $7.30 \pm 0.10^{\mathrm{b}}$ \\
\hline TBR & $7.55 \pm 0.15^{\mathrm{c}}$ \\
\hline CWR & $7.30 \pm 0.10^{\mathrm{b}}$ \\
\hline
\end{tabular}

*The values are expressed as the mean \pm S.D. $(\mathrm{n}=3)$. Means with different letters indicate a significant difference within the parameter measured at $p<0.05$ (Duncan's test). $\mathrm{SRR}=$ Solok red rice; $\mathrm{CRR}=$ Cianjur red rice; $\mathrm{SBR}=$ Solok black rice; $\mathrm{TBR}=\mathrm{Tangerang}$ black $\mathrm{Rrce}$; $\mathrm{CWR}=$ Cianjur white rice. 


\subsection{Starch gelatinization profile}

The data obtained in the starch gelatinization analysis using RVA consisted of the pasting temperature, peak viscosity value (MV), breakdown viscosity (VB), setback viscosity (SV) and stirring stability of the starch samples at $50^{\circ} \mathrm{C}$ (Table 5). The MV was measured when the starch paste reached maximum viscosity during the heating phase. VB shows the stability of viscosity to heating while SV shows the tendency of the starch to retrograde (Wang et al., 2015).

Table 5. The starch gelatinization profiles of the five different rice varieties from different areas in Indonesia*.

\begin{tabular}{cccccc}
\hline \multirow{2}{*}{ Rice } & $\begin{array}{c}\text { Pasting temp } \\
\left({ }^{\circ} \mathbf{C}\right)\end{array}$ & $\begin{array}{c}\text { Peak } \\
(\mathbf{c P})\end{array}$ & $\begin{array}{c}\text { Breakdown } \\
(\mathbf{c P})\end{array}$ & $\begin{array}{c}\text { Setback } \\
(\mathbf{c P})\end{array}$ & $\begin{array}{c}\text { Final } \\
(\mathbf{c P})\end{array}$ \\
\hline SRR & $87.54 \pm 0.24^{\mathrm{b}}$ & $1986.50 \pm 12.7^{\mathrm{b}}$ & $1160.25 \pm 28.32^{\mathrm{d}}$ & $1983.25 \pm 16.34^{\mathrm{c}}$ & $2809.50 \pm 18.67^{\mathrm{b}}$ \\
\hline $\mathrm{CRR}$ & $87.99 \pm 0.45^{\mathrm{b}}$ & $2160.50 \pm 17.8^{\mathrm{c}}$ & $1070.00 \pm 11.67^{\mathrm{c}}$ & $2440.25 \pm 12.38^{\mathrm{d}}$ & $3530.75 \pm 13.12^{\mathrm{d}}$ \\
\hline SBR & $87.08 \pm 0.92^{\mathrm{b}}$ & $2260.75 \pm 10.8^{\mathrm{d}}$ & $957.50 \pm 12.45^{\mathrm{b}}$ & $2503.50 \pm 17.34^{\mathrm{e}}$ & $3806.75 \pm 11.27^{\mathrm{e}}$ \\
\hline TBR & $89.10 \pm 0.65^{\mathrm{c}}$ & $1412.25 \pm 6.8^{\mathrm{a}}$ & $574.75 \pm 18.80^{\mathrm{a}}$ & $1661.75 \pm 20.23^{\mathrm{b}}$ & $2499.25 \pm 8.64^{\mathrm{a}}$ \\
\hline $\mathrm{CWR}$ & $85.80 \pm 1.17^{\mathrm{a}}$ & $3469.00 \pm 14.5^{\mathrm{e}}$ & $2116.25 \pm 24.00^{\mathrm{e}}$ & $1604.25 \pm 19.82^{\mathrm{a}}$ & $2957.00 \pm 5.37^{\mathrm{c}}$ \\
\hline
\end{tabular}

*The values are expressed as the mean \pm standard deviation $(\mathrm{n}=3)$. Means with different letters in the same column indicate a significant difference within the parameter measured at $p<0.05$ (Duncan's test). SRR = Solok red rice; CRR = Cianjur red rice; SBR = Solok black rice; $\mathrm{TBR}=$ Tangerang black rice; $\mathrm{CWR}=$ Cianjur white rice.

During gelatinization, the starch granule swells and the hydrogen bonding is disrupted, leading to the breakdown of the starch granule structure, uncoiling of the double helix and disappearance of the birefringence characteristic. On cooling, the disaggregated starch granules rearrange themselves in a different way from their native structure, which is referred to as retrogradation. According to Wang et al. (2015), the degree of rupture of the starch structure during gelatinization and the new structure formed during retrogradation affect starch digestibility.

The gelatinization temperatures of the rice granules of the samples (SRR; CRR; SBR; TBR and CWR) ranged from $85.80{ }^{\circ} \mathrm{C}$ to $89.10^{\circ} \mathrm{C}$ (Table 5), CWR showing the lowest pasting temperature. However, the gelatinization peaks (cP) ranged from 3469.00 to 1412.25 , CWR showing the highest viscosity and TBR the lowest viscosity. Granule breakdown or rupture ranged from $574.75 \mathrm{cP}$ to $2116.25 \mathrm{cP}$, and since CWR showed the highest value for this parameter, the starch of this rice sample was probably less resistant or less stable to the heating process. The setback values ranged from $1604.25 \mathrm{cP}$ to $2503.50 \mathrm{cP}$, showing a tendency for the starch granules to retrograde. SBR showed the highest setback value of $2503.50 \mathrm{cP}$ and was therefore the most susceptible to retrogradation, followed by CBR, SRR and TBR. In contrast, CWR was the most resistant to retrogradation since it had the lowest setback viscosity value. A high amylose content contributes to a tendency for the starch paste to retrograde during the cooling phase (Wang et al., 2015), and previous research on rice from Thailand, China and Sri Lanka showed that the amylose content of the black rice samples ranged between $9.66 \%$ and $25.49 \%$ whereas that of the red rice samples ranged between $7.47 \%$ and $42.02 \%$, depending on the varieties (Sompong et al. 2011).

\subsection{Starch digestibility}

The in vitro digestibility of the starch of the five rice varieties studied ranged from $56.10 \%$ to $87.35 \%$, as shown in Figure 2. 


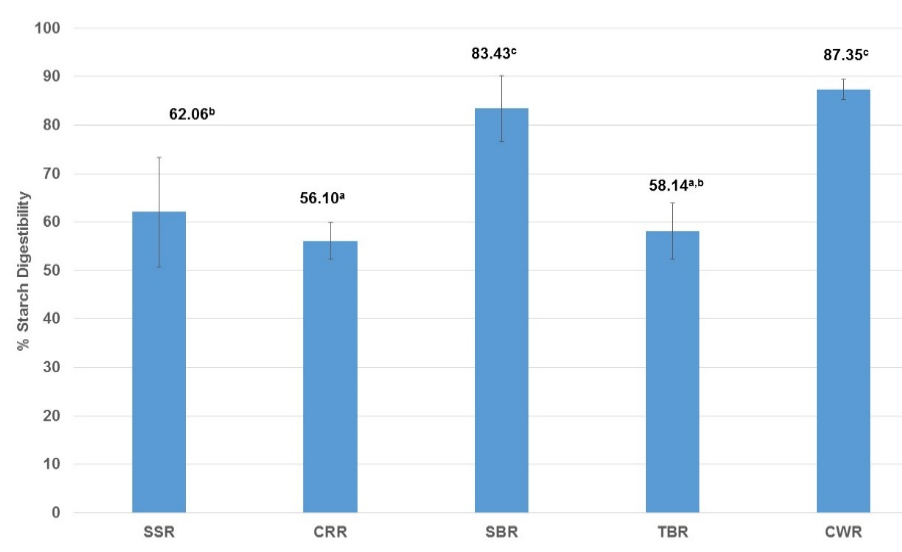

Figure 2. Starch digestibility of the five different rice varieties from different areas in Indonesia. The values are the mean \pm standard deviation $(n=3)$. Numbers followed by the same letter are not significantly different at the $5 \%$ test level (Duncan's test). $\mathrm{SRR}=$ Solok red rice, $\mathrm{CRR}=$ Cianjur red rice, $\mathrm{SBR}=$ Solok black rice, $\mathrm{TBR}=$ Tangerang black rice, $\mathrm{CWR}=$ Cianjur white rice.

According to Figure 2, the samples TBR and SRR did not differ significantly one from the other, showing digestibility values from $58.14 \%$ to $62.06 \%$, while the digestibility of the samples SBR and CWR ranged from $83.43 \%$ to $87.35 \%$ also showing no significant difference. However, the digestibility of the sample CRR varied significantly from those of the other samples, with a value of $56.10 \%$. According to Deepa et al. (2010), the starch of red and black rice is less digestible than that of white rice. Less digestible starch has been reported to have some benefits associated with a reduction in the risk of various chronic degenerative diseases such as type 2 diabetes (Bello-Perez et al., 2018). The digestibility data is in agreement with the gelatinization profiles shown in Table 5, where CWR showed the lowest gelatinization temperature and setback viscosity value and was the most digestible, followed by SBR. The other rice varieties (SRR, CRR, SBR and TBR) showed higher gelatinization temperatures and setback viscosities, and were less digestible.

\subsection{The total phenolic compound and total flavonoid contents and the antioxidant capacities of the raw and cooked rice samples}

The total phenolic compound and total flavonoid contents and the antioxidant capacities of the five rice samples tested in this study, both raw and cooked, are presented in Table 6.

Table 6. The total phenolic compound and total flavonoid contents and the antioxidant capacities of the raw and cooked red, black and white rice samples from different areas of Indonesia*.

\begin{tabular}{|c|c|c|c|c|c|c|}
\hline \multirow[t]{2}{*}{ Rice } & \multicolumn{2}{|c|}{$\begin{array}{c}\text { Total Phenolic content } \\
\text { (mg GAE/g) }\end{array}$} & \multicolumn{2}{|c|}{$\begin{array}{c}\text { Total Flavonoid content } \\
(\mathrm{mg} \mathrm{QE} / \mathrm{g})\end{array}$} & \multicolumn{2}{|c|}{$\begin{array}{c}\text { Antioxidant Capacity } \\
\text { (mg AEAC/g) }\end{array}$} \\
\hline & Raw & Cooked & Raw & Cooked & Raw & Cooked \\
\hline SRR & $5.309 \pm 0.283^{b}$ & $3.036 \pm 0.264^{b}$ & $19.245 \pm 1.491^{\mathrm{e}}$ & $2.024 \pm 0.140^{\mathrm{d}}$ & $8.600 \pm 0.825^{\mathrm{d}}$ & $0.388 \pm 0.038^{a}$ \\
\hline CRR & $5.812 \pm 0.614^{b}$ & $3.151 \pm 0.159^{b}$ & $14.215 \pm 0.651^{\mathrm{d}}$ & $1.144 \pm 0.198^{b}$ & $9.650 \pm 0.636^{\mathrm{e}}$ & $0.446 \pm 0.038^{b}$ \\
\hline SBR & $5.121 \pm 0.521^{b}$ & $3.630 \pm 0.048^{\mathrm{c}}$ & $9.824 \pm 1.546^{\mathrm{c}}$ & $0.999 \pm 0.032^{b}$ & $6.308 \pm 0.318^{c}$ & $0.511 \pm 0.013^{b}$ \\
\hline TBR & $5.068 \pm 0.924^{b}$ & $3.150 \pm 0.024^{b}$ & $7.720 \pm 0.217^{b}$ & $1.430 \pm 0.133^{\mathrm{c}}$ & $1.790 \pm 0.075^{\mathrm{b}}$ & $0.761 \pm 0.020^{\mathrm{c}}$ \\
\hline CWR & $1.512 \pm 0.022^{\mathrm{a}}$ & $2.372 \pm 0.076^{\mathrm{a}}$ & $0.634 \pm 0.084^{\mathrm{a}}$ & $0.434 \pm 0.045^{\mathrm{a}}$ & $0.563 \pm 0.236^{\mathrm{a}}$ & $0.333 \pm 0.031^{\mathrm{a}}$ \\
\hline
\end{tabular}

As shown in Table 6, the total phenolic compound contents of the raw SRR, CRR, SBR and TBR rice samples did not vary significantly, but the CWR sample showed a significantly lower total phenolic compound content $(1.512 \pm 0.022 \mathrm{mg} \mathrm{GAE} / \mathrm{g})(p=0.05)$. With respect to the cooked rice, the phenolic compound contents of the CRR, TBR and SRR samples did not vary significantly, with values of 
$3.150 \pm 0.264,3.150 \pm 0.024$ and $3.036 \pm 0.264 \mathrm{mg} \mathrm{GAE} / \mathrm{g}$, respectively. However, the CWR and SBR samples showed significant differences with values of $2.372 \pm 0.076$ and $3.630 \pm 0.048 \mathrm{mg} \mathrm{GAE} / \mathrm{g}$, respectively. The heat treatment can damage phenolic components which are sensitive to heat (Piga et al., 2003). Walter et al. (2013) reported a significant decrease in the total soluble phenolic compound contents of rice with light brown, red and black pericarps after processing (polishing and parboiling), which the authors assumed was due to leaching of the phenolic compounds into the water.

A comparison of the total flavonoid contents (Table 6) of the raw SRR, CRR, SBR, TBR and CWR samples showed significant differences between the samples, the SRR sample showing the highest value $(19.245 \pm 1.491 \mathrm{mg} \mathrm{QE} / \mathrm{g})$ and the CWR sample the lowest $(0.634 \pm 0.084 \mathrm{mg} \mathrm{QE} / \mathrm{g})$. With respect to the flavonoid contents of the cooked rice samples, there were significant differences between the SRR, TBR and CWR samples with values of $2.024 \pm 0.140,1.430 \pm 0.133$ and $0.434 \pm 0.045 \mathrm{mg}$ QE/g but the cooked CRR and SBR samples did not present significant differences. A literature review of the antioxidant compound contents of a wide variety of pigmented and unpigmented rice varieties found a higher total flavonoid content in black rice varieties as compared to red rice varieties (Goufo \& Rindade, 2014). Another study reported that the total flavonoid content of Chak-hao Angangba brown rice was higher than those of the Chak-hao Amubi (black) and Chak-hao Poireiton (purple) rice varieties (Reddy et al., 2016). It was also previously reported that the phenolic compound content of rice samples which had undergone cooking decreased by 84.16\% (Pérez-Jiménez \& Saura-Calixto, 2005). As can be seen in Table 6, after cooking, the total flavonoid contents of all the rice samples decreased.

In this study the antioxidant capacity was measured by the DPPH method, which measures the DPPH reducing ability of the antioxidants present in the sample. The data in Table 6 shows that all the rice samples (SRR; CRR; SBR; TBR and CWR) had significant antioxidant capacity, the sample CRR showing the highest activity $(9.650 \pm 0.636 \mathrm{mg} \mathrm{AEAC/g})$. However, amongst the cooked rice samples, only TBR presented a significant difference in relation to the others, with a value of $(0.761 \pm 0.020 \mathrm{mg} \mathrm{AEAC} / \mathrm{g})$. Similar to the flavonoid contents, a decrease in the antioxidant capacity of the rice samples was observed after cooking. A different response in the total antioxidant capacity was reported elsewhere (Zaupa et al., 2015), where the FRAP method was used to determine the total antioxidant capacity of black, red, and white rice cooked by different methods (boiling and the risotto method) the difference being in the volume of water used to cook the rice, which was 3.6: $1 \mathrm{w} / \mathrm{w}$ for the risotto method and 20:1 w/w for boiling. The total antioxidant capacity of all the types of rice, except the black rice, was significantly reduced by both boiling and the risotto method. However, the black rice exhibited significantly higher antioxidant capacity after cooking by the risotto method, although it was significantly reduced by boiling. In another study, differences in the DPPH radical scavenging activity between different rice varieties were also reported, and the authors presumed this was a result of different compositions and concentrations of the secondary metabolites present in the rice samples studied due to genotype diversity and climatic disparities (Reddy et al., 2016).

\subsection{Correlation between the total phenolic compound content, total flavonoid content and the in vitro antioxidant capacity}

The Pearson's correlation analysis between the total phenolic compound content, total flavonoid content and the antioxidant activity in the rice samples showed a significantly positive correlation $(p<0.001)$.

The total phenolic compound content of the rice samples had a moderately positive correlation with the antioxidant capacity $(\mathrm{r}=0.725)$, while the total flavonoid content showed a stronger positive correlation $(\mathrm{r}=0.870)$. The pigmented and non-pigmented rice samples were reported to contain diverse types of phenolic compounds (e.g. ferulic acid and its derivatives, protocatechuic acid and $p$-coumaric acid) and flavonoids (e.g. quercetin) which possess antioxidant capacity (Zaupa et al., 2015). 


\section{Conclusions}

This study showed that different rice varieties had significant differences in their physical properties (hardness, colour and gelatinization profile), chemical properties (chemical composition, total phenolic compound and total flavonoid contents, and antioxidant capacity), and starch digestibility. The area of cultivation also contributed significantly to the rice quality parameters tested. The most important findings of this study were the effects of these variations on the contents of the bioactive compounds in the rice and in the rice digestibility, since these factors are closely associated with the health claims of pigmented rice. The pigmented rice had higher total phenolic compound and total flavonoid contents and higher antioxidant capacity than white rice but was less digestible, except for the Solok black rice. However, the total phenolic compound and total flavonoid contents, and the antioxidant capacity of all the rice samples tested decreased after cooking. The results of this study suggested that the cultivation origin and the method of cooking should be taken into consideration when making health claims on the labels of particular types of rice.

\section{References}

Anderson, A. K., Guraya, H. F., James, C., \& Salvaggio, L. (2002). Digestibility and pasting properties of rice starch heatmoisture treated at the melting temperature (Tm). Starch/Starke, 54(9), 401-409. https://doi.org/10.1002/1521379X(200209)54:9<401::AID-STAR401>3.0.CO;2-Z.

Association of Official Analytical Chemists - AOAC. (2000). Official methods of analysis of the Association of Official Analytical Chemists (17th ed). Gaithersburg: AOAC.

Badan Pusat Statistik - BPS. (2012). Statistik daerah Kabupaten Tangerang. Tangerang (ID): BPS. Retrieved in 2014, December 14, from https://tangerangkab.bps.go.id/subject/151/iklim.html\#subjekViewTab3

Badan Pusat Statistik - BPS. (2013). Kota Solok dalam angka. Solok (ID): BPS. Retrieved in 2014, December 14, from https://solokkota.bps.go.id/subject/151/iklim.html\#subjekViewTab3

Badan Standarisasi Nasional - BSN. (2008). SNI 6128-2008: Beras (Rice). Retrieved in 2018, September 16, from http://www.foodstation.co.id/doc/Fwater\%206128-2015.pdf

Bello-Perez, L. A., Flores-Silva, P. C., Agama-Acevedo, E., \& Tovar, J. (2018). Starch digestibility: past, present, and future. Journal of the Science of Food and Agriculture, In press. PMid:29427318. http://dx.doi.org/10.1002/jsfa.8955

Chang, C. C., Yang, M. H., Wen, H. M., \& Chern, J. C. (2002). Estimation of total flavonoid content in propolis by two complementary colorimetric methods. Yao Wu Shi Pin Fen Xi, 10(3), 178-182.

Chen, P. N., Kuo, W. H., Chiang, C. L., Chiou, H. L., Hsieh, Y. S., \& Chu, S. C. (2006). Black rice anthocyanins inhibit cancer cells invasion via repressions of MMPsand u-PA expression. Chemico-Biological Interactions, 63(3), 218-229. PMid:16970933. http://dx.doi.org/10.1016/j.cbi.2006.08.003

Deepa, G., Singh, V., \& Naidu, K. A. (2010). Comparative study on starch digestibility, glycemic index and resistant starch of pigmented ('Njavara' and 'Jyothi') and a non-pigmented ('IR 64') rice varieties. Journal of Food Science and Technology, 47(6), 644-649. PMid:23572699. http://dx.doi.org/10.1007/s13197-010-0106-1

Gelay, D. R., \& Bryant, R. J. (2009). Seed physicochemical characteristics of field-grown US weedy red rice (Oryza sativa) biotypes: contrasts with commercial cultivars. Journal of Cereal Science, 49(2), 239-245.

http://dx.doi.org/10.1016/j.jcs.2008.10.007

Goufo, P., \& Rindade, H. (2014). Rice antioxidants: phenolic acids, flavonoids, anthocyanins, proanthocyanidins, tocopherols, tocotrienols, $Y$-oryzanol, and phytic acid. Food Science and Nutrition, 2(2), 75-104.

Hansen, T. H., Lombi, E., Fitzgerald, M., Laursen, K. H., Frydenvang, J., Husted, S., Boualaphanh, C., Resurreccion, A. Howard, D. L., De Jonge, M. D., Paterson, D., \& Schjoerring, J. K. (2012). Losses of essential mineral nutrients by polishing of rice differ among genotypes due to contrasting grain hardness and mineral distribution. Journal of Cereal Science, 56(2), 307315. http://dx.doi.org/10.1016/j.jcs.2012.07.002

Hosoda, K., Sasahara, H., Matsushita, K., Tamura, Y., Miyaji, M., \& Matsuyama, H. (2018). Anthocyanin and proanthocyanidin contents, antioxidant activity, and in situ degradability of black and red rice grains. Asian-Australasian Journal of Animal Sciences, 31(8), 1213-1220. PMid:29514441. http://dx.doi.org/10.5713/ajas.17.0655

Kubo, I., Masuoka, N., Xiao, P., \& Haraguchi, H. (2002). Antioxidant activity of dodecyl gallate. Journal of Agricultural and Food Chemistry, 50(12), 3533-3539. PMid:12033824. http://dx.doi.org/10.1021/jf011250h

Official Website of Cianjur District. (2013). Geographical location. Retrieved in 2014, December 14, from https://cianjurkab.go.id/profil-cianjur/letak-geografis/

Park, C. E., Kim, Y. S., Park, K. J., \& Kim, B. K. (2012). Changes in physicochemical characteristics of rice during storage at different temperatures. Journal of Stored Products Research, 48, 25-29. http://dx.doi.org/10.1016/j.jspr.2011.08.005

Pérez-Jiménez, J., \& Saura-Calixto, F. (2005). Literature data may underestimate the actual antioxidant capacity of cereals. Journal of Agricultural and Food Chemistry, 53(12), 5036-5040. PMid:15941353. http://dx.doi.org/10.1021/jf050049u 
Piga, A., Del Caro, A., \& Corda, G. (2003). Influence of drying parameters on polyphenols and antioxidant activity. Journal of Agricultural and Food Chemistry, 51(12), 3675-3681. PMid:12769544. http://dx.doi.org/10.1021/jf021207+

Reddy, C. K., Kimi, L., \& Haripriya, S. (2016). Variety difference in molecular structure, functional properties, phytochemical content and antioxidant capacity of pigmented rice. Journal of Food Measurement and Characterization, 10(3), 605-613. http://dx.doi.org/10.1007/s11694-016-9344-x

Shao, Y., Hu, Z., Yu, Y., Mou, R., Zhu, Z., \& Beta, T. (2018). Phenolic acids, anthocyanins, proanthocyanidins, antioxidant activity, minerals and their correlations in non-pigmented, red, and black rice. Food Chemistry, 239, 733-741. PMid:28873629. http://dx.doi.org/10.1016/j.foodchem.2017.07.009

Shao, Y., Xu, F., Sun, X., Bao, J., \& Beta, T. (2014). Identification and quantification of phenolic acids and anthocyanins as antioxidants in bran, embryo and endosperm of white, red and black rice kernels (Oryza sativa L.). Journal of Cereal Science, 59(2), 211-218. http://dx.doi.org/10.1016/j.jcs.2014.01.004

Sompong, R., Siebenhandl-Ehn, S., Linsberger-Martin, G., \& Berghofer, E. (2011). Physicochemical and antioxidative properties of red and black rice varieties from Thailand, China and Sri Lanka. Food Chemistry, 124(1), 132-140.

http://dx.doi.org/10.1016/j.foodchem.2010.05.115

Strycharz, S., \& Shetty, K. (2002). Effect of Agrobacterium rhizogenes on phenolic content of Mentha pulegium elite clonal line phytoremediation applications. Process Biochemistry, 38(2), 287-293. http://dx.doi.org/10.1016/S0032-9592(02)00078-X

Sumczynski, D., Kotásková, E., Družbíková, H., \& Mlček, J. (2016). Determination of contents and antioxidant activity of free and bound phenolics compounds and in vitro digestibility of commercial black and red rice (Oryza sativa L.) varieties. Food Chemistry, 211, 339-346. PMid:27283641. http://dx.doi.org/10.1016/j.foodchem.2016.05.081

Verma, D. K., \& Srivastav, P. P. (2017). Proximate composition, mineral content and fatty acids analyses of aromatic and nonaromatic indian rice. Rice Science, 24(1), 21-31. http://dx.doi.org/10.1016/j.rsci.2016.05.005

Walter, M., Marchesan, E., Massoni, P. F. S., Silva, L. P., Sartori, G. M. S., \& Ferreira, R. B. (2013). Antioxidant properties of rice grains with light brown, red and black pericarp colors and the effect of processing. Food Research International, 50(2), 698703. http://dx.doi.org/10.1016/j.foodres.2011.09.002

Wang, S., Li, C., Copeland, L., Niu, Q., \& Wang, S. (2015). Starch retrogradation: A comprehensive review. Comprehensive Reviews in Food Science and Food Safety, 14(5), 568-585. http://dx.doi.org/10.1111/1541-4337.12143

Yadav, R. B., Khatkar, B. S., \& Yadav, B. S. (2007). Morphological, physicochemical and cooking properties of some Indian rice (Oryza sativa L.) cultivars. Agricultural Technology (Thailand), 3(2), 203-210.

Yawadio, R., Tanimori, S., \& Morita, N. (2007). Identification of phenolic compound isolated from pigmented rice and their aldose reductase inhibitory activities. Food Chemistry, 101(4), 1616-162. http://dx.doi.org/10.1016/j.foodchem.2006.04.016

Yodmanee, S., Karrila, T. T., \& Pakdeechanuan, P. (2011). Physical, chemical and antioxidant properties of pigmented rice grown in Southern Thailand. International Food Research Journal, 18(3), 901-906.

Zaupa, M., Calani, L., Del Rio, D., Brighenti, F., \& Pellegrini, N. (2015). Characterization of total antioxidant capacity and (poly) phenolic compounds of differently pigmented rice varieties and their changes during domestic cooking. Food Chemistry, 187, 338-347. PMid:25977035. http://dx.doi.org/10.1016/j.foodchem.2015.04.055 